\title{
Genetic characterization of Toxoplasma gondii from Qinghai vole, Plateau pika and Tibetan ground-tit on the Qinghai-Tibet Plateau, China
}

\author{
Xiao-Xuan Zhang ${ }^{1,2 \dagger}$, Zhong-Zi Lou ${ }^{1 \dagger}$, Si-Yang Huang ${ }^{1 *}$, Dong-Hui Zhou', Wan-Zhong Jia ${ }^{1 *}$, Chunlei Su,3 \\ and Xing-Quan Zhu' ${ }^{1,4}$
}

\begin{abstract}
Background: The distribution of genetic diversity of Toxoplasma gondii in wildlife is of interest to understand the transmission of this parasite in the environment. Limited information on T. gondii genotypes has been reported in wildlife in China. The objective of this study was to carry out the genetic characterization of $T$. gondii isolates from wild animals on the Qinghai-Tibet Plateau.

Methods: Using PCR and multilocous polymerase chain reaction-restriction fragment length polymorphism (PCR-RFLP) technology, we detected genetic diversity of T. gondii isolates from Qinghai vole, Plateau pika and Tibetan ground-tit in these regions.

Results: In total, 183 brain tissues of different wild animals, including 48 Qinghai vole (Microtus fuscus), 101 Plateau pika (Ochotona curzoniae) and 34 Tibetan ground-tit (Pseudopodoces humilis), were tested for T. gondii infection. 11 of these were found to be positive for the T. gondii B1 gene by PCR amplification. These positive DNA samples were typed at 10 genetic markers, including 9 nuclear loci (SAG1, 5'-and 3'-SAG2, alternative SAG2, BTUB, GRA6, L358, PK1, C22-8, c29-2), and an apicoplast locus Apico. Six were successfully genotyped at eight or more genetic loci, and were grouped to three distinct genotypes. Four samples belonged to ToxoDB Genotype \#10 and the other two samples were identified as two new genotypes (http://toxodb.org/toxo/).
\end{abstract}

Conclusions: To our knowledge, this is the first report of genetic typing of $T$. gondii isolates in wildlife on the Qinghai-Tibet Plateau, China. The results show that there is a potential risk for the transmission of this parasite through the wildlife in this region.

Keywords: Toxoplasma gondii, Genetic typing, PCR-RFLP, Wildlife, Qinghai-Tibet Plateau

\section{Background}

The obligate intracellular parasite Toxoplasma gondii is an important protozoan that infects warm-blooded vertebrates, including birds and mammals, and one third of the world human population is chronically infected [1-4]. Intermediate hosts such as humans can be infected by ingesting tissue cysts from undercooked meat or consuming food or

\footnotetext{
* Correspondence: siyang.huang@hotmail.com; jiawanzhong@caas.cn ${ }^{\dagger}$ Equal contributors

'State Key Laboratory of Veterinary Etiological Biology, Key Laboratory of Veterinary Parasitology of Gansu Province, Lanzhou Veterinary Research Institute, Chinese Academy of Agricultural Sciences, Lanzhou, Gansu Province 730046, PR China

Full list of author information is available at the end of the article
}

drinking water contaminated by oocysts shed in the feces of infected cats [5-8].

In general, all $T$. gondii isolates were considered a single species without geographical boundaries, and with limited genetic diversity $[5,9]$. However, recent studies of T. gondii in humans and animals in South America indicated that these isolates are genetically and biologically different from those in North America and Europe where the T. gondii population structure is highly clonal and composed mainly of 4 distinct lineages, i.e., Types I, II, III and 12 [5,10-16]. The severe toxoplasmosis in immunocompetent human patients was associated with atypical genotypes in South America $[17,18]$. We have previously identified limited genotypes in $T$. gondii 
isolates from humans, cats, pigs, sheep and birds in China [19-23], but there is little genetic information on $T$. gondii isolates from wild animals in China, especially on the Qinghai-Tibet Plateau, a region with a unique ecosystem. In the present article we describe the genetic characterization of $T$. gondii isolates from wild animals on the Qinghai-Tibet Plateau.

\section{Methods}

\section{The investigated regions}

The present study was conducted in Qinghai Province $\left(31^{\circ}-39^{\circ} \mathrm{N}, 88^{\circ}-103^{\circ} \mathrm{E}\right)$, People's Republic of China, which lies on the northeastern Tibetan Plateau, covering an area of 724,000 square kilometers, with an average altitude of 3,000 meters above sea level. The annual precipitation is below $400 \mathrm{~mm}$ and average annual temperature is between $5.7^{\circ} \mathrm{C}$ and $8.5^{\circ} \mathrm{C}$, and the difference in daily temperature is large. The surveyed regions are of typical continental climate-altitude.

\section{Naturally infected wildlife}

The animals examined in this study were captured by simple equipment named as 'mousetrap' by local governments to protect the grass of the Qinghai-Tibet Plateau. Brain tissue samples were collected from 48 Qinghai voles (Microtus fuscus), 101 Plateau pikas (Ochotona curzoniae) and 34 Tibetan ground-tits (Pseudopodoces humilis) from the Qinghai-Tibet Plateau. The tissues were kept in $70 \%$ ethanol directly after collection until further study.

\section{Extraction of genomic DNA and genetic characterization} Genomic DNA was extracted from approximately $100 \mathrm{mg}$ of brain tissues by sodium dodecyl sulphate/proteinase $\mathrm{K}$ treatment, column-purified (Tiangen ${ }^{\mathrm{Tw}}$, Beijing, China) and eluted into $50 \mu \mathrm{H}_{2} \mathrm{O}$ according to the manufacturer's recommendations. A nested PCR targeting the T. gondii B1 gene was performed to detect possible infection with $T$. gondii [24]. DNA samples giving positive B1 amplification were then used for genetic characterization.

Genetic characterization of $T$. gondii isolates from these wild animals was carried out using the multilocus PCR-RFLP method $[21,23,25,26]$. In brief, the target DNA sequences were amplified by multiplex PCR using external primers for all 10 markers [25,26]. Six reference $T$. gondii strains were included as the positive controls including GT1, PTG, CTG, MAS, TgCgCa1 and TgCatBr5 (Table 1). The PCR reaction (25 $\mu \mathrm{l})$ composed of $1 \times$ PCR buffer, $0.2 \mathrm{mM}$ of each primer, $200 \mu \mathrm{M}$ dNTPs, $2 \mathrm{mM} \mathrm{MgCl}_{2}, 0.2 \mathrm{U}$ of HotStart Taq DNA polymerase (TAKARA, Japan). The PCR amplification was performed using a thermal cycler (PTC 200, Bio-RAD). All samples were incubated at $95^{\circ} \mathrm{C}$ for 5 min to activate the DNA polymerase, then 30 cycles of PCR at $95^{\circ} \mathrm{C}$ for $30 \mathrm{~s}, 55^{\circ} \mathrm{C}$ for $60 \mathrm{~s}$ and $72^{\circ} \mathrm{C}$ for $90 \mathrm{~s}$. Multiplex PCRamplified products were diluted 1:1 in sterile, doubledistilled water, and then used for nested PCR amplifications with internal primers for each marker, separately $[25,26]$. A similar program was used for the nested PCR. The nested PCR amplifications were carried out with the annealing temperature at $60^{\circ} \mathrm{C}$ for $60 \mathrm{~s}$ for all the markers except Apico, which was amplified at $55^{\circ} \mathrm{C}$. The nested PCR products were digested with restriction enzymes for $1 \mathrm{~h}$, and the temperature for each enzyme was used according to the instructions for each enzyme. The restriction fragments were resolved in $2.5 \%$ agarose gel, stained by the GoldenView ${ }^{\text {tw }}$, and photographed using a gel documentation system (UVP GelDoc-ItTM Imaging System, Cambridge, U.K.).

\section{Results}

Of 183 DNA samples, 11 were positive for the $T$. gondii B1 gene by PCR amplification, including 6 from Qinghai voles $(6 / 48,12.5 \%), 4$ from Plateau pikas $(4 / 101,3.96 \%)$ and 1 from Tibetan ground-tit (1/34, 2.94\%). Six DNA samples showed genotyping results, 3 from Plateau pikas, 2 from Qinghai voles, and 1 from Tibetan ground-tit (Table 1). Due to low DNA concentration, 5 of the 11 positive samples could not be genotyped completely or nearly completely, and was not used. Three genotypes were identified from the 11 positive samples, including Type I and two new genotypes (Table 1).

\section{Discussion}

The Qinghai-Tibetan Plateau is a region that has a low pressure of oxygen and high ultraviolet radiation, where the altitude is high and the temperature is low. Little is known of the prevalence and genetic characterization of $T$. gondii in this extremely inhospitable high-altitude environment.

The plateau pikas are underground-dwelling relatives of rabbits, prefer to live in elevations of 3,100 to $5,000 \mathrm{~m}$, mostly on the Tibetan Plateau. The plateau pikas are considered to be a reservoir of environmental spread of $T$. gondii, because they are prodigious breeders and serve as the favourite food of carnivores that live in the area, such as brown bears and wolves. $T$. gondii was first detected from plateau pika in 1994 using the indirect hemagglutination assay (IHA) [27]. Our present data first indicated that the three isolates from plateau pika on the Qinghai-Tibet Plateau belonged to Type I. This result is different from previous studies that showed the genotype ToxoDB PCR-RFLP genotype \#9 was predominant in cats and other animals in southern, southwestern, and central parts of China [19-22,28]. This difference is probably because these animals live in a unique environment. Results of the present study 
Table 1 Summary of genotyping of Toxoplasma gondii from Qinghai vole, Plateau pika and Tibetan ground-tit on the Qinghai-Tibet Plateau, China

\begin{tabular}{|c|c|c|c|c|c|c|c|c|c|c|c|c|c|c|}
\hline Isolate ID & Host & Tissue & Location & SAG1 & $5^{\prime}+3^{\prime}$ SAG2 & Alternative SAG2 & BTUB & GRA6 & c22-8 & c29-2 & L358 & PK1 & Apico & Genotype \\
\hline$\overline{\text { GT1 }}$ & Goat & & United States & । & । & I & । & । & । & I & । & । & । & Reference, Type I, ToxoDB \#10 \\
\hline PTG & Sheep & & United States & $\|/\| \|$ & $\|$ & $\|$ & $\|$ & $\|$ & $\|$ & $\|$ & $\|$ & $\|$ & $\|$ & Reference, Type II, ToxoDB \#1 \\
\hline CTG & Cat & & United States & $\|/\| \|$ & III & III & III & III & III & III & III & III & III & Reference, Type III, ToxoDB \#2 \\
\hline MAS & Human & & France & $\mathrm{u}-1^{*}$ & । & $\|$ & III & III & $\mathrm{u}-1^{*}$ & I & । & III & I & Reference, ToxoDB \#17 \\
\hline TgCgCa1 & Cougar & & Canada & । & । & $\|$ & III & $\|$ & $\|$ & $u-1^{*}$ & । & $u-2^{*}$ & I & Reference, ToxoDB \#66 \\
\hline TgCatBr5 & Cat & & Brazil & । & III & III & $\|$ & III & । & । & । & $\mathrm{u}-1^{*}$ & । & Reference, ToxoDB \#19 \\
\hline TgOcDR40 & Plateau pika & Brain & Qinghai, China & । & I & । & I & I & I & I & I & I & I & Type I, ToxoDB \#10 \\
\hline TgOcDR1 & Plateau pika & Brain & Qinghai, China & I & । & I & । & । & I & I & I & । & I & Type I, ToxoDB \#10 \\
\hline TgMfDR39 & Qinghai vole & Brain & Qinghai, China & । & । & । & । & । & । & I & । & । & । & Type I, ToxoDB \#10 \\
\hline TgOcDR18 & Plateau pika & Brain & Qinghai, China & । & । & । & । & । & । & । & । & $\mathrm{Nd}$ & । & Type I, ToxoDB \#10 \\
\hline TgMfDR28 & Qinghai vole & Brain & Qinghai, China & $\|/\| \|$ & । & I & । & I & $\|$ & I & $\mathrm{Nd}$ & । & । & New genotype \\
\hline TgPhDR1 & Tibetan ground-tit & Brain & Qinghai, China & I & 1 & $\|$ & III & $\mathrm{Nd}$ & $\mathrm{Nd}$ & 1 & 1 & 1 & 1 & New genotype \\
\hline
\end{tabular}

${ }^{*} \mathrm{u}-1$ and $\mathrm{u}-2^{*}$ represent unique RFLP genotypes, respectively.

$\mathrm{Nd}$ : represents no data. 
indicate that Type I is the major clonal $T$. gondii genotype circulating in plateau pikas. To further identify the genetic diversity of $T$. gondii in plateau pikas, more samples from different geographical regions on the QinghaiTibet Plateau should be included.

Qinghai vole ( $M$. fuscus) is a sub-species of small rodents on the Qinghai-Tibet Plateau. Vole populations can expand rapidly within a very short period of time, and many predators, such as martens, raccoons, owls, hawks, the red-tailed hawk, weasels, cats and dogs prey on voles. The seroprevalence of T. gondii infection in Microtus fortis was 29\% in Hunan province [29] and $50.4 \%$ in Jilin province [30], China. Thus, voles can serve as a reservoir of environmental spread of $T$. gondii.

Little information is available about $M$. fuscus infection with $T$. gondii. The present study showed by PCR that a proportion (12.5\%) of M. fuscus were positive for the B1 gene of $T$. gondii, and genetic analysis showed that one isolate is Type I (ToxoDB genotype \#10), which may be a predominant genotype on the Qinghai-Tibet Plateau, and another isolate presents a new genotype (Table 1). In the present study, we also found that one Tibetan ground-tit was positive for the infection of $T$. gondii, and the isolate presents a new genotype (Table 1). A limitation of the present study is that the sizes of samples are not large, especially for Qinghai voles, only 48 samples were collected. To obtain more accurate information about the genetic diversity of $T$. gondii in these wild animals, more samples from different regions on the Qinghai-Tibet Plateau should be included. Although the role of wildlife in the transmission of $T$. gondii to humans and other animals is not fully understood [31], rodents and small animals are important intermediate hosts of $T$. gondii because they serve as a potential source of infection for some predators and may therefore contribute to the parasite's spread.

The present work provides new genetic information about $T$. gondii infection in wildlife on the QinghaiTibet Plateau, China. T. gondii infection in wildlife is very important because people can become infected via eating undercooked meat.

\section{Conclusion}

The present study genetically characterized $T$. gondii isolates from Qinghai vole, Plateau pika and Tibetan ground-tit on the Qinghai-Tibet Plateau, China, for the first time, and three T. gondii genotypes were determined (Type I and two new genotypes). These results provide new genetic information about $T$. gondii infection in wildlife on the Qinghai-Tibet Plateau, China, and have implications for our better understanding of the genetic diversity of $T$. gondii.

\section{Competing interests}

The authors declare that they have no competing interests.

\section{Authors' contributions}

XQZ, SYH and WZJ conceived and designed the study and wrote and critically revised the manuscript. XXZ, ZZL and DHZ performed the experiments, analyzed the data, and drafted the manuscript. CS helped in the study design, study implementation, and manuscript revision. All authors read and approved the final manuscript

\section{Acknowledgments}

Project support was provided by the National Natural Science Foundation of China (Grant Nos. 31228022, 31172316, 31101812 and 31230073) and the Science Fund for Creative Research Groups of Gansu Province (Grant No. 1210RJIA006).

\section{Author details}

${ }^{1}$ State Key Laboratory of Veterinary Etiological Biology, Key Laboratory of Veterinary Parasitology of Gansu Province, Lanzhou Veterinary Research Institute, Chinese Academy of Agricultural Sciences, Lanzhou, Gansu Province 730046, PR China. ${ }^{2}$ Department of Veterinary Medicine, College of Agriculture, Yanbian University, Yanji, Jilin Province 133000, PR China. ${ }^{3}$ Department of Microbiology, The University of Tennessee, Knoxville, TN 37996, USA. ${ }^{4}$ College of Animal Science and Veterinary Medicine, Heilongjiang Bayi Agricultural University, Daqing, Heilongjiang Province 163319, PR China.

Received: 15 September 2013 Accepted: 7 October 2013 Published: 9 October 2013

\section{References}

1. Dubey JP: Toxoplasmosis of Animals and Humans. secondth edition. Boca Raton, Florida: CRC Press; 2010:313.

2. Chen J, Xu MJ, Zhou DH, Song HQ, Wang CR, Zhu XQ: Canine and feline parasitic zoonoses in China. Parasit Vectors 2012, 5:152.

3. Tian YM, Dai FY, Huang SY, Deng ZH, Duan G, Zhou DH, Yang JF, Weng YB, Zhu XQ, Zou FC: First report of Toxoplasma gondii seroprevalence in peafowls in Yunnan Province, Southwestern China. Parasit Vectors 2012, 5:205

4. Nardoni S, Angelici MC, Mugnaini L, Mancianti F: Prevalence of Toxoplasma gondii infection in Myocastor coypus in a protected Italian wetland. Parasit Vectors 2011, 4:240.

5. Ajzenberg D, Banuls AL, Tibayrenc M, Darde ML: Microsatellite analysis of Toxoplasma gondii shows considerable polymorphism structured into two main clonal groups. Int J Parasitol 2002, 32:27-38.

6. Zhou P, Chen Z, Li HL, Zheng H, He S, Lin RQ, Zhu XQ: Toxoplasma gondi infection in humans in China. Parasit Vectors 2011, 4:165.

7. Montoya JG, Liesenfeld O: Toxoplasmosis. Lancet 2004, 363:1965-1976.

8. Cenci-Goga BT, Ciampelli A, Sechi P, Veronesi F, Moretta I, Cambiotti V, Thompson PN: Seroprevalence and risk factors for Toxoplasma gondii in sheep in Grosseto district, Tuscany, Italy. BMC Vet Res 2013, 9:25.

9. Sibley LD, Boothroyd JC: Virulent strains of Toxoplasma gondii comprise a single clonal lineage. Nature 1992, 359:82-85.

10. Dubey JP, Graham DH, Blackston CR, Lehmann T, Gennari SM, Ragozo AM, Nishi SM, Shen SK, Kwok OC, Hill DE, Thulliez P: Biological and genetic characterisation of Toxoplasma gondii isolates from chickens (Gallus domesticus) from Sao Paulo, Brazil: unexpected findings. Int J Parasitol 2002, 32:99-105.

11. Howe DK, Sibley LD: Toxoplasma gondii comprises three clonal lineages: correlation of parasite genotype with human disease. J Infect Dis 1995, 172:1561-1566.

12. Dubey JP, Sundar N, Gennari SM, Minervino AH, Farias NA, Ruas JL, Dos Santos TR, Cavalcante GT, Kwok OC, Su C: Biologic and genetic comparison of Toxoplasma gondii isolates in free-range chickens from the northern Para state and the southern state Rio Grande do Sul, Brazil revealed highly diverse and distinct parasite populations. Vet Parasitol 2007, 143:182-188.

13. Dubey JP, Cortes-Vecino JA, Vargas-Duarte JJ, Sundar N, Velmurugan GV, Bandini LM, Polo LJ, Zambrano L, Mora LE, Kwok OC, Smith T, Su C: Prevalence of Toxoplasma gondii in dogs from Colombia, South America and genetic characterization of T. gondii isolates. Vet Parasitol 2007, 145:45-50.

14. Dubey JP, Sundar N, Hill D, Velmurugan GV, Bandini LA, Kwok OC, Majumdar D, Su C: High prevalence and abundant atypical genotypes of 
Toxoplasma gondii isolated from lambs destined for human consumption in the USA. Int J Parasitol 2008, 38:999-1006.

15. Darde ML, Bouteille B, Pestre-Alexandre M: Isoenzyme analysis of 35 Toxoplasma gondii isolates and the biological and epidemiological implications. J Parasitol 1992, 78:786-794.

16. Khan A, Dubey JP, Su C, Ajioka JW, Rosenthal BM, Sibley LD: Genetic analyses of atypical Toxoplasma gondii strains reveal a fourth clonal lineage in North America. Int J Parasitol 2011, 41:645-655.

17. Carme B, Bissuel F, Ajzenberg D, Bouyne R, Aznar C, Demar M, Bichat S, Louvel D, Bourbigot AM, Peneau C, Neron P, Dardé ML: Severe acquired toxoplasmosis in immunocompetent adult patients in French Guiana. J Clin Microbiol 2002, 40:4037-4044.

18. Delhaes L, Ajzenberg D, Sicot B, Bourgeot P, Darde ML, Dei-Cas E, HoufflinDebarge $V$ : Severe congenital toxoplasmosis due to a Toxoplasma gondii strain with an atypical genotype: case report and review. Prenat Diagn 2010, 30:902-905.

19. Dubey JP, Zhu XQ, Sundar N, Zhang H, Kwok OC, Su C: Genetic and biologic characterization of Toxoplasma gondii isolates of cats from China. Vet Parasitol 2007, 145:352-356.

20. Zhou P, Nie H, Zhang LX, Wang HY, Yin CC, Su C, Zhu XQ, Zhao JL: Genetic characterization of Toxoplasma gondii isolates from pigs in China. J Parasitol 2010, 96:1027-1029.

21. Zhou P, Sun XT, Yin CC, Yang JF, Yuan ZG, Yan HK, Zhu XQ, Zou FC: Genetic characterization of Toxoplasma gondii isolates from pigs in southwestern China. J Parasitol 2011, 97:1193-1195.

22. Zhou P, Zhang H, Lin RQ, Zhang DL, Song HQ, Su C, Zhu XQ: Genetic characterization of Toxoplasma gondii isolates from China. Parasitol Int 2009, 58:193-195.

23. Huang SY, Cong W, Zhou P, Zhou DH, Wu SM, Xu MJ, Zou FC, Song HQ, Zhu XQ: First report of genotyping of Toxoplasma gondii isolates from wild birds in China. J Parasitol 2012, 98:681-682.

24. Jiang HH, Huang SY, Zhou DH, Zhang XX, Su C, Deng SZ, Zhu XQ: Genetic characterization of Toxoplasma gondii from pigs from different localities in China by PCR-RFLP. Parasit Vectors 2013, 6:227.

25. Su C, Shwab EK, Zhou P, Zhu XQ, Dubey JP: Moving towards an integrated approach to molecular detection and identification of Toxoplasma gondii. Parasitology 2010, 137:1-11.

26. Su C, Zhang X, Dubey JP: Genotyping of Toxoplasma gondii by multilocus PCR-RFLP markers: a high resolution and simple method for identification of parasites. Int J Parasitol 2006, 36:841-848.

27. Cao YF, Ye RR: Prevalence of Toxoplasma gondii infection in Plateau Pika by IFA. J Qinghai Vet 1994, 11:39.

28. Chen ZW, Gao JM, Huo XX, Wang L, Yu L, Halm-Lai F, Xu YH, Song WJ, Hide $\mathrm{G}$, Shen JL, et al: Genotyping of Toxoplasma gondii isolates from cats in different geographic regions of China. Vet Parasitol 2011, 183:166-170.

29. Zhang SY, Jiang SF, He YY, Pan CE, Zhu M, Wei MX: Serologic prevalence of Toxoplasma gondii in field mice, Microtus fortis, from Yuanjiang, Hunan Province, People's Republic of China. J Parasitol 2004, 90:437-438.

30. Zhang Y, Xu D, Cao L, Gao Y, Xia X, Zhang Z, Wang T, Wei F, Yang G, Liu Q: High Prevalence of Toxoplasma gondii infection in Microtus fortis by semi-nested PCR from Jilin Province, Northeastern China. J Parasitol 2013, 99:580-582.

31. Dubey JP, Humphreys JG, Thulliez P: Prevalence of viable Toxoplasma gondii tissue cysts and antibodies to $T$. gondii by various serologic tests in black bears (Ursus americanus) from Pennsylvania. J Parasitol 1995, 81:109-112.

doi:10.1186/1756-3305-6-291

Cite this article as: Zhang et al: Genetic characterization of Toxoplasma gondii from Qinghai vole, Plateau pika and Tibetan ground-tit on the Qinghai-Tibet Plateau, China. Parasites \& Vectors 2013 6:291.

\section{Submit your next manuscript to BioMed Central and take full advantage of:}

- Convenient online submission

- Thorough peer review

- No space constraints or color figure charges

- Immediate publication on acceptance

- Inclusion in PubMed, CAS, Scopus and Google Scholar

- Research which is freely available for redistribution 